№ 28 (2019) стор. 187-191

The National Academy of Fine Arts and Architecture

Ukrainian Academy of Fine Art. Research and Methodology Papers

ISSN 2411-3034

Website: http://naoma-science.kiev.ua/

УДК 003.077:615.851](510)

ORCHID iD 0000-0002-7226-5329

DOI: https://doi.org/10.33838/naoma.28.2019.187-191

Dr. Biyun Zhang (张碧云)

Zhejiang University of Technology, Hangzhou, Zhejiang, 310014

zhangbiyun2013@163.com

\title{
TRADITIONS AND INNOVATIONS IN APPLIED ART: CALLIGRAPHY AS AN ESSENTIAL PART OF CHINESE ARTISTIC CULTURE AND ITS THERAPEUTIC EFFECT ON MENTAL HEALTH
}

Abstract. Calligraphy, as one of the artistic and cultural treasures of China, has a very long history and symbolizes the spirit of Chinese culture. With the advancement of mental health research, calligraphy has become an indispensable force and has gained significant results in the treatment of mental illness. This article summarizes the relationship between calligraphy and human emotions and analyzes the positive effect of calligraphy art therapy on mental health through research on the development of calligraphy therapy.

Keywords: calligraphy, China, therapy, mental health, psychotherapy

\section{ТРАДИЦІЇ ТА ІННОВАЦІЇ У ПРИКЛАДНОМУ МИСТЕЦТВІ: КАЛІГРАФІЯ ЯК ВАЖЛИВА ЧАСТИНА КИТАЙСЬКОЇ ХУДОЖНЬОЇ КУЛЬТУРИ ТА ЇЇ ТЕРАПЕВТИЧНИЙ ВПЛИВ НА ПСИХІЧНЕ ЗДОРОВ'Я \\ Біюнь Джан}

Анотація. Каліграфія як одне із найбільш відомих та характерних мистецьких та культурних надбань Китаю має тисячолітню історію, завдяки чому вона багато в чому символізує та уособлює дух китайської культури. 3 розвитком досліджень психічного здоров'я каліграфія стала широковживаною i навіть неодмінною терапевтичною практикою, яка змогла дати очевидні й доведені результати в лікуванні психічних захворювань.

У цій статті узагальнено взаємозв'язок між каліграфічними вправами та емоційним станом людини й проаналізовано позитивний вплив каліграфічної арттерапії на психічне здоров'я шляхом дослідження розвитку каліграфічної терапії. На основі аналізу літературних джерел показано, що мистецтво каліграфії може забезпечити інтелектуальний розвиток, культивувати позитивні почуття, покращити емоційний стан та рівновагу і підвищити нашу естетичну здатність до оцінювання та мистецьких звершень, у такий спосіб усуваючи втому та стимулюючи розумову діяльність. На підставі цього зроблено висновок про унікальність ролі каліграфії в психотерапії. Показано, що завданням сучасної мультидисциплінарної терапії та комплексного аналізу особистості з метою покращення якості ї̈ життя є узагальнення та використання багатовікового досвіду в описаній галузі знань. Взявши до уваги історію розвитку каліграфічної терапії зроблений прогноз щодо подальшого посилення уваги до традиційної культури та розвитку психології в Китаї, а також відповідного збільшення кількості наукових досліджень щодо використання каліграфії в галузі арттерапії психічних захворювань. Зроблено висновок, що каліграфія - це не лише одна з основ китайської національної культури, але й ї̈ ідейний фундамент, що хоч і відіграє важливу роль у психотерапії, та все ж потребує подальшого вивчення та аналізу його унікальних можливостей у галузі охорони здоров'я, що має велике практичне значення. 
Отримані під час дослідження результати можуть бути використані для глибшого вивчення теми іншими авторами з метою розробки терапевтичної та педагогічної практик.

Ключові слова: каліграфія, Китай, терапія, психічне здоров'я, психотерапія.

Formulation of the problem. Initially the calligraphy was referred to the use of brush in writing, but along with the social progress and cultural development, the form of calligraphy had also changed. Thus, nowadays calligraphy is considered as an artistic technique and, at the same time, as an artistic technique that affects the emotion and mental component of personality by means of artistic expression. Therefore, in order to more focused practical application of calligraphy, there is a need for systematization and detailed description of these effects.

Relevance of research. Calligraphy, as the essence of national wisdom, is an important carrier of the Chinese national cultural heritage and its essential part. Calli-graphy cultivates better human qualities, refine sentiments and also develop the body and mind of the learner. Calligraphy has not only been widely practiced in China, but also favored by foreigners, who has been coming to China from far abroad to learn calligraphy or buy calligraphy works as early as in the period of the Tang Dynasty. A kind of calligraphy originated in China is called “書道, Shodō” in Japan, and “서예, Seoye” in Korea, both literary meaning a kind of writing art.

With its further cultural and ideological progress China has continuously dee-pened psychological research, this way making the role of calligraphy in the treat-ment of mental illness increasingly important.

Studies have shown that when people write Chinese characters, the left and right brains, which both have different functions, work simultaneously. This means writing Chinese characters can promote the development of intelligence and personal development. In addition, studies have also shown that young people who have practiced calligraphy for a long time are more likely to form stable emotions and moderate temperaments. Nowadays, calligraphy exercises have become an important part of psychotherapy in major psychiatric hospitals all over the China, and have brought remarkable results. This is why a systematic and generalized description of the above effects and practices is relevant to make them applicable by a wider international community.
Connection of the author's work with important scientific and practical tasks. Since ancient times, there have been many clear proofs of the positive effect of calligraphy on mental health. For example, Qiaofan He wrote in his book Mind Chapter: "calligraphy means the expression of emotion and soothing of depression in one's heart.", from which we can see that calligraphy can soothe a depression and regulate emotions. Xiong Yang of the Han Dynasty had also put forward the thesis of "calligraphy being the painting of heart", where the "heart" referred to one's thoughts and emotions, which means calligraphy works are the direct psychological reflection of calligraphers soul and mind.

Calligraphy can help get rid of negative emotions, so that psychological balance can be achieved. Calligraphy can express relaxed and happy feelings, it can also help to get free of negative emotions. Most calligraphers in ancient times were known for their longevity, such as Xun Ouyang, Zhenqing Yan, Gongquan Liu and many others, one of the important reasons of that phenomenon could be their long time and extensive calligraphy practice, which possibly helped them get rid of negative emotions and to promote mental health.

Psychology of art, originated in the late nineteenth century and the early twentieth century, is related to the interaction between artistic creative activity and human psychological activities, it is aimed at explanation of the meaning of artistic works by using the principles of psychology to give people an ability to more profoundly enjoy the art works. In China, many psychologists are also beginning to pay particular attention to the rich psychological thoughts contained in Chinese traditional culture, including Chinese calligraphy art.

Thus, the task of modern multidisciplinary therapy and comprehensive analysis of personality in order to improve the quality of life is to generalize and use centuries of experience in the described field of knowledge, which this article deals with.

Analysis of recent research and publications. Numerous contemporary studies analyze the influence of calligraphy on mental health. Professor Shangren Gao at Department of Psychology, Hong 
Kong University in his book "Calligraphy Arts Psychology" says learning Chinese characters requires particular wisdom, because they are more complex then characters of other writing systems. When a person is writing, their vision and spirit need to be highly concentrated, rewriting of the same Chinese character would arise a new feeling. When practicing calligraphy, people experience breathing, blood pressure, and heartbeat changes. Therefore, calligraphy can be used for attention deficit hyperactivity disorder (ADHD), Alzheimer's disease, mental patients, autistic disorder etc.

Numerous studies have shown that calligraphy exercises have the comprehensive, dynamic and positive role in perception, thinking and cognition. While writing, a calligrapher can experience such positive effects as being quick-minded and quick responsive. Calligraphy exercises can also normalize the heart rate, breathing and blood pressure, as well as relieve excessive stress. Professor Shangren Gao and his colleagues believe that calligraphy exercises, just as the Qigong, can reduce the arousal level of the body's autonomic nervous system and improve the activity level of the non-autonomic nervous system so as to relieve the heart rate and blood pressure.

Indication of previously unsolved parts of the general problem to which the article is devoted. This study focuses on the impact of calligraphy on mental health and the corresponding practical application of this artistic technique.

Novelty of scientific research. The author for the first time applies historical analysis of the sources directly along with the results of modern research and practic-al applications.

Methodological and general scientific significance of author's developments. The methodological and scientific value of the author's research lies in the gene-ralization and systematization of the available data and knowledge as well as in the identification and revealing of general rules and peculiarities of the topic.

Presenting main material. Based on the history of calligraphic therapy, we can give a prognosis that with increasing attention to traditional culture and the development of psychology in China, the amount of scientific research on the use of calli-graphy in the field of mental illness therapy will increase.

The concepts of “Qin (Qing 情 / Xin 信)?”, "Chess", "Calligraphy" and "Painting" have taken root in Chinese people's hearts already in ancient times. Whether at home, at an educational institution or at work, calligraphy works can be seen everywhere, such as the ones containing well known Chinese saying "Keep cool and you'll win". Both office work and study require quiet environment and full concentration, so a calligraphy work can influence people in an imperceptible way, enabling them to calm down and be deeply absorbed into work.

Calligraphy itself is often a full catharsis of the author's emotions, whereas cor-responding studies have confirmed that those who are good at emotional catharsis have better psychical health, stronger immune system, and recover from illness, in-cluding mental ones, faster.

Calligraphy is diverse in terms of fonts and is changing a lot in the art of compo-sition, this is why a calligrapher exercises a wide range of physical moves and mental activities, which enable people to increase self-control ability and broaden their vision. Chinese characters are hieroglyphic, containing endless philosophical ideas; people would often be inspired when carefully comprehending the pattern of Chinese characters. Patients who have experienced mental illness are often sensitive, manic, suspicious, inferior to others and have other mental failures or inadequacies; calligraphy shows a therapeutic effect in these patients, which deserves further discussion and investigation.

Ultimately, mental illness is caused by a poor emotional state, while calligraphy exercises can regulate people's emotions and make them relax. While practicing cal-ligraphy, people must fully concentrate their attention and calm down; calligraphy can make people temporarily forget all the routine and troubles, release negative emotions, balance the body and relax. Calligraphy and aesthetic appreciation are in-separable, as practicing the calligraphy is also the process of aesthetic appreciation. Through enjoying the beauty of the art of calligraphy, people can get physical and moral satisfaction. Furthermore, the improvement of calligraphic skills can provide people with a sense of confidence and accomplishment, making possible to maintain a good emotional state.

A number of studies show that calligraphy exercises can help develop healthy psychological qualities. Calligraphy can refine people's sentiments, 
moral values, enhance their aesthetic taste and develop intelligence.

Psychologists have found that calligraphy exercises can make the left and right brains work simultaneously and enhance their coordination, this way improving the reaction ability and affecting the development of intelligence. The level of calligraphic skills is positively correlated with the right brain reaction sensitivity. The better those skills are, the higher is the sensitivity of the right brain. Nowadays calligraphy education can train students' thinking ability, memory, imagination, that is intelligence as a whole through activities such as copying and creation.

Copying is an important stage in the study of calligraphy. Calligraphy exercises are inseparable from copying; therefore, it is extremely important to train the learner's eyesight and mental outlook. Copying of the famous calligraphic works and analysis of the font, mastering the brush technique and composition of the copy can give the learner an ability to master the things as a whole and a keener mind.

Calligraphy can play a role for the treatment of depression, while this role can be divided into psychological aspect and physiological aspect. Psychologically, the role of calligraphy is to make patients feel happy and concentrated, to improve their writ-ing accuracy and coordination, which would increase their self-confidence.

Calligraphy therapy has a significant position in China. Although it is not as close to everyday life as literature and comedy, it is closer to art and can be considered the pure form of art, which is directly related to the spiritual temperament of a person. No matter what kind of temperament, boldness or tenderness, can be expressed through a brush in the hand, it produces a complex feeling beyond the ordinary one and can also be called a psychological structure of art. This type of psychological structure fully demonstrates all the potential, talent and temperament of a person, and calligraphers can obtain unlimited enjoyment from it.

Major disasters are likely to have a tremendous impact on a persons' physical and mental health. For example, the impact of earthquake trauma on children's mind may lead to failure to carry out normal learning and the decline in quality of life. For such children is easier and more comfortable to receive calligraphy therapy, which has own cultural value and is an important step in healing of posttraumatic stress response in children, then other types of treatment. Calligraphy has significant effect on intrusion, avoidance and emotional awakening caused by an earthquake. Passive contemplation of calligraphy works and active calligraphy practice play an irreplaceable role in the treatment of mental illness. From a physiological point of view, calligraphy exercises require the correct posture, straight body position, flat feet, preferably in a standing posture and flexibly, which helps to normalize the metabolism.

Conclusions. Calligraphy art can provide us with nourishment for the mind, cultivate our sentiments, put our troubles out of mind and enhance our aesthetic appreciation ability and artistic accomplishments, in this way eliminating fatigue and regulating mental activities. All this contributes to the unique role calligraphy in psychotherapy.

It can be concluded that calligraphy is not only the essence of the wisdom of the Chinese nation, but also its ideological foundation. It also plays an important role in psychotherapy. However it still requires further study and exploration of its unique possibilities in healthcare, which is of great practical significance.

Possible further use of the results. The results gained from this research can be used for a deeper study of the topic by other authors to develop therapeutic and pedagogical practices.

\section{Цитовані праці}

Bingfeng, Li. Learning Calligraphy with Heart - Research II on "Calligraphy Therapy" in Mental Health Education of College Students. [J] Novel Remark. 2011. Print.

Gang, Zheng. The Role of Calligraphy Therapy for Depression. [J] Med J Chin People Health. 2008. Print.

Yan, Zong. Research on Psychological Intervention of Traumatic Stress Response of Children Suffering Earthquake through Calligraphy Psychological Treatment. [J] Chinese Journal of Social Medicine. 2011. Print. 
Zhiye, Wang. Brief Talk the Role of Calligraphy in Psychotherapy. [J] Education for Chinese After-school. 2012. Print.

\section{References}

Bingfeng, Li. Learning Calligraphy with Heart - Research II on "Calligraphy Therapy" in Mental Health Education of College Students. [J] Novel Remark. 2011. Print.

Gan, Zheng. The Role of Calligraphy Therapy for Depression. [J] Med J Chin People Health. 2008. Print. Yan, Zong. Research on Psychological Intervention of Traumatic Stress Response of Children Suffering Earthquake through Calligraphy Psychological Treatment. [J] Chinese Journal of Social Medicine. 2011. Print.

Zhiye, Wang. Brief Talk the Role of Calligraphy in Psychotherapy. [J] Education for Chinese After-school. 2012. Print.

Подано до редакиії 7.06.2019

\section{Рецензенти:}

Стасенко В. В. - кандидат мистецтвознавства, професор;

Ковальчук О. В. - кандидат мистецтвознавства, доцент. 